\title{
Artikel
}

\section{Nadeelcompensatie onder de Omgevingswet: hoe een stelselherziening in het omgevingsrecht leidt tot een systeemwijziging van het nadeelcompensatierecht}

Mr. dr. G.M. (Berthy) van den Broek*

\section{Inleiding}

Op 29 juni 2018 werd het wetsvoorstel Invoeringswet Omgevingswet aangeboden aan de Tweede Kamer. ${ }^{1}$ Het wetsvoorstel bevat in hoofdstuk 1 de aanvullingen en wijzigingen van de Omgevingswet, die de regering voor een goede invoering noodzakelijk acht. Een van de aanvullingen betreft een nadeelcompensatieregeling, die in afdeling 15.1 van de Omgevingswet zal worden opgenomen.

De Omgevingswet leidt tot een grootschalige wijziging van het omgevingsrecht. $\mathrm{Bij}$ het ontwerpen van een nadeelcompensatieregeling ter aanvulling van de Omgevingswet heeft de regering als uitgangspunt genomen dat het systeem van de nadeelcompensatie moet aansluiten bij de stelselherziening van het omgevingsrecht.

Voor de vormgeving van de nadeelcompensatieregeling acht de regering de volgende elementen van de Omgevingswet van belang:

* Mr. dr. G.M. van den Broek is docent bij de Afdeling Staats- en Bestuursrecht van de Universiteit Utrecht en als onderzoeker verbonden aan het Utrecht Centre for Water, Oceans and Sustainability Law. Bovendien is zij lid van de Tijdelijke Commissie Mijnbouwschade Groningen.

1. Kamerstukken II 2017/18, 34 986, nr. 1.
1. De Omgevingswet makt de totstandkoming van globale, uitnodigende omgevingsplannen en het werken met open normen mogelijk.

2. De Omgevingswet en het omgevingsplan hebben een brede reikwijdte.

3. De taken en bevoegdheden zijn verdeeld over verschillende bestuursorganen en overheidslagen. In het omgevingsrecht is sprake van getrapte besluitvorming.

4. Met de Omgevingswet wordt een brede participatie van burgers en bedrijven bij de totstandkoming van besluiten nagestreefd.

De stelselherziening in het omgevingsrecht heeft consequenties voor de vormgeving van de nadeelcompensatieregeling in hoofdstuk 15 van de Omgevingswet. Bij het opstellen van de nadeelcompensatieregeling in de Omgevingswet zijn door de minister keuzes gemaakt die fundamenteel afwijken van de keuzes die de Awbwetgever in 2013 heeft gemaakt. De stelselherziening in het omgevingsrecht leidt daarmee tot wijzigingen in het systeem van het nadeelcompensatiestelsel, zoals de formele wetgever dat in 2013 had vastgesteld.

De eerste keuze is dat art. 15.1 Omgevingswet (hierna: Ow) een wettelijke, limitatieve lijst van schadeoorzaken bevat, waarop uitsluitend besluiten zijn vermeld die rechtstreeks bindend zijn voor burgers. Een tweede keuze is dat bij 'indirecte schade' de peildatum voor de 
schadevergoeding wordt verschoven van het omgevingsplan naar de verlening van de omgevingsvergunning of de start van de vergunningsvrije activiteit. ${ }^{2}$ Een derde keuze is dat in art. $15.5 \mathrm{t} / \mathrm{m} 15.7 \mathrm{Ow}$ materiële bepalingen zijn opgenomen die afwijken van de in de jurisprudentie ontwikkelde criteria.

De consultatieversie die de toenmalige minister van Infrastructuur en Milieu op 5 januari 2017 publiceerde, riep reacties op die veelal betrekking hadden op de hierboven genoemde drie - tamelijk fundamentele - keuzes. Er waren instemmende, maar zeker ook kritische reacties, die niet alleen in het kader van de internetconsultatie en vanuit de praktijk, maar ook in de rechtswetenschappelijke literatuur naar voren werden gebracht. Deze (kritische) reacties zijn niet expliciet terug te vinden in de memorie van toelichting (hierna: MvT), maar klinken wel door in de - soms uitgebreide - onderbouwing van de uitgangspunten van de nadeelcompensatieregeling in hoofdstuk 15 van de Ow. In deze bijdrage onderzoek ik of, en zo ja, in hoeverre de reacties op de consultatieversie en het advies van de Afdeling advisering van de Raad van State hebben geleid tot aanpassingen van het wetsvoorstel. Daarbij neem ik de hiervoor genoemde drie keuzes voor de vormgeving van de nadeelcompensatieregeling als leidraad.

\section{De verhouding tussen afdeling $15.1 \mathrm{Ow}$ en titel 4.5 Awb}

Het wetsvoorstel voor een nadeelcompensatieregeling in de Ow zet een streep door de keuze van de wetgever om een uniforme nadeelcompensatieregeling in de Algemene wet bestuursrecht (Awb) op te nemen. Met het wetsvoorstel wordt namelijk gekozen voor een bijzondere regeling van nadeelcompensatie in de $\mathrm{Ow}$, die op belangrijke onderdelen afwijkt van de algemene regeling in de Awb. Afdeling 15.1 van de Ow zal gelden als een 'lex specialis', die voorrang heeft op de algemene regeling voor nadeelcompensatie in titel 4.5 van de Awb.

De nadeelcompensatieregeling in de $\mathrm{Ow}$ zal op belangrijke onderdelen afwijken van de algemene regeling voor nadeelcompensatie in titel 4.5 van de Awb. Deze algemene regeling is onderdeel van de Wet nadeelcompensatie en schadevergoeding bij onrechtmatige besluiten (Wns). ${ }^{3}$ Het is de bedoeling dat titel 4.5 van de Awb voorafgaand of in ieder geval gelijktijdig met de $\mathrm{Ow}$ in werking zal treden. ${ }^{4}$ In art. $15.1 \mathrm{Ow}$ wordt bepaald dat titel 4.5 van de Awb alleen van toepassing is op de toe-

2. Indirecte schade wordt in de MvT omschreven als 'schade die wordt veroorzaakt door activiteiten in de omgeving van een perceel van een burger of in de omgeving van een bedriif'. Kamerstukken II 2017/18, 34986, nr. 3, p. 18

3. Deze wet verscheen weliswaar al in 2013 in het Staatsblad, maar is nog niet in werking getreden (Stb. 2013, 50).

4. Kamerstukken II 2017/18, 34 986, nr. 3, p. 19. kenning van schade als bedoeld in art. 4:126, eerste lid, Awb, als het gaat om schade die wordt veroorzaakt door een van de in het eerste lid opgesomde besluiten of regels. Deze opsomming is limitatief en exclusief: wanneer een schadeoorzaak niet is genoemd in art. 15.1, eerste lid, Ow kan niet via de weg van art. 4:126 Awb om nadeelcompensatie worden gevraagd.

\subsection{De noodzaak tot inperking van de ruime reikwijdte van art. 4:126 Awb}

Art. 4:126 Awb bevat een brede reikwijdte, waardoor een benadeelde een aanvraag om nadeelcompensatie kan indienen zodra een bestuursorgaan schade veroorzaakt in de rechtmatige uitoefening van een publiekrechtelijke bevoegdheid of taak. In 2015 schreef ik met Tjepkema een preadvies voor de Vereniging voor Bouwrecht waarin wij constateerden dat een dergelijk ruim toepassingsbereik tot problemen leidt bij gelede normstelling of getrapte besluitvorming, zoals die in het bestuursrecht gebruikelijk is. ${ }^{5}$ Er kunnen daarnaast problemen rijzen in de situatie dat meerdere bestuursorganen, op diverse overheidsniveaus, betrokken zijn bij de (sectorale) besluitvorming over een bepaald project, zoals de aanleg van een weg, spoorweg of een dijkverbreding. De rechten en plichten van burgers zijn in dat geval in een keten van met elkaar samenhangende overheidsbesluiten vastgelegd. In deze keten zijn vaak meerdere besluiten aan te wijzen die schade kunnen veroorzaken. In dit soort gevallen is het wenselijk dat de wetgever een regeling treft, waarin wordt bepaald aan welk besluit en aan welk bestuursorgaan de schade wordt toegerekend en op welk moment een aanvraag om nadeelcompensatie wordt ingediend.

Een voorbeeld van een getrapte besluitvorming zijn de bepalingen in verordeningen die een vergunningstelsel in het leven roepen. Deze bepalingen houden een verbod in om zonder vergunning een bepaalde activiteit te verrichten. De vraag is op welk moment een aanvraag om nadeelcompensatie het beste kan worden beoordeeld. Is dat het moment waarop de bepaling, die een verbod behoudens vergunning bevat, in werking treedt, of het moment waarop een besluit wordt genomen omtrent de verlening van de vergunning? In ons preadvies stelden Tjepkema en ik voor om de schade pas te vergoeden op het moment dat een besluit omtrent de vergunningverlening is genomen. Pas op dat moment is immers duidelijk of de activiteiten waarvoor de vergunningplicht geldt, mogen worden verricht, en zo ja, onder welke voorwaarden. Meer in het algemeen is het wenselijk dat schade door algemeen verbindende voorschriften die ruime, discretionaire bevoegdheden toekennen aan een bestuursorgaan om een besluit te nemen, waarin de feiten, belangen en omstandigheden voor het concrete geval nog nader kunnen worden afgewogen, pas wordt vergoed nadat met toepassing van de in het algemeen

5. G.M. van den Broek \& M.K.G. Tjepkema, De reikwijdte en rechtsgrondslag van nadeelcompensatie in het omgevingsrecht (Publicatie van de Vereniging voor Bouwrecht, nr. 43), Den Haag: Instituut voor Bouwrecht 2015, par. 2.5 
verbindend voorschrift toegekende bevoegdheid een besluit is genomen.

Dit is een categorie die men kan aanduiden als een 'doorschuifregeling': een regeling waarin de aansprakelijkheid wordt doorgeschoven tot het moment waarop een besluit wordt genomen waarin toestemming wordt gegeven voor of randvoorwaarden worden gesteld aan activiteiten. Een voorbeeld is art. 6.1, zesde lid, Wro. Ook art. 15.1 , tweede lid, Ow is een voorbeeld van een bepaling waarin het moment van de aanvang van de overheidsaansprakelijkheid wordt doorgeschoven. Als voor een activiteit een omgevingsvergunning is vereist op grond van een regel in het omgevingsplan, een waterschapsverordening of een omgevingsverordening, geldt alleen de omgevingsvergunning voor die activiteit als een schadeveroorzakend besluit.

Een tweede categorie is de 'voorrangsregeling'. Wanneer de besluitvorming omtrent een project via verschillende sectorale sporen verloopt, is het in het omgevingsrecht niet ongebruikelijk dat de wetgever één besluit als schadeveroorzakend besluit aanwijst. In sommige gevallen is dat het hoogste, kaderstellende sectorale besluit dat op rijksniveau wordt vastgesteld en waarbij het voor de implementatie noodzakelijk is dat een gemeente een besluit neemt. Een voorbeeld is een tracébesluit of een luchthavenindelingbesluit op basis van de Wet luchtvaart (Wlv). Deze besluiten die op rijksniveau worden vastgesteld, moeten door de gemeente nog worden geimplementeerd in het bestemmingsplan. In andere gevallen wordt als schadeveroorzakend besluit aangewezen het besluit van de overheid die het initiatief neemt en de regie voert over de uitvoering van het project, maar wel de toestemming van een ander overheidsorgaan nodig heeft (bijvoorbeeld art. 7.16 Waterwet).

In de genoemde voorbeelden is er sprake van meerdere besluiten van verschillende bestuursorganen die schade kunnen veroorzaken. Om problemen te voorkomen bij de vaststelling van de aansprakelijkheid voor schade die omwonenden en ondernemers lijden, is het in deze gevallen wenselijk dat de wetgever bepaalt aan welk besluit de schade wordt toegerekend en welk bestuursorgaan aansprakelijk is. Er zijn meerdere voorbeelden van formeel-wettelijke bepalingen waarin de wetgever een dergelijke voorrangsregeling heeft opgenomen. Zo bepaalt art. 7.16 Waterwet dat afdeling 6.1 van de Wro buiten toepassing blijft voor zover een belanghebbende een beroep doet of kan doen op art. 7.14 Waterwet, en bepaalt art. 8.31, derde lid, Wlv dat afdeling 6.1 van de Wro buiten toepassing blijft wanneer een belanghebbende een beroep doet of kan doen op art. 8.31, eerste lid, Wlv.

In het preadvies dat Tjepkema en ik in 2015 schreven, hebben wij voorgesteld dat de wetgever de hierboven genoemde keuzes in titel 4.5 van de Awb zou vastleggen. De gesignaleerde problemen die verband houden met een getrapte besluitvorming of een verdeling van bevoegdheden tussen bestuursorganen, komen in het gehele bestuursrecht voor en dus niet alleen in het omgevingsrecht. Dit is een belangrijk argument om de reikwijdte van de Awb-regeling in te perken. In situaties waarin de schade wordt veroorzaakt door een samenhangend geheel van overheidsbesluiten is het noodzakelijk dat de wetgever een regeling treft waaruit blijkt op welk moment en bij welk bestuursorgaan een benadeelde een aanvraag om nadeelcompensatie kan indienen. Dit voorkomt complexe juridische vragen over causaal verband en de toerekening van schade aan de verschillende bestuursorganen.

De wetgever heeft in de Ow zowel een 'doorschuifregeling' als een 'voorrangsregeling' opgenomen. Art. 15.1 bevat in het tweede en derde lid bepalingen voor de situatie van getrapte besluitvorming of een samenhangend geheel van besluiten ter realisering van een project. Art. 15.1, tweede lid, Ow wijst de omgevingsvergunning aan als schadeoorzaak, wanneer een omgevingsvergunning is vereist op grond van een regel in een omgevingsplan, waterschapsverordening of omgevingsverordening. Daarmee wordt de schade doorgeschoven. Art. 15.1, derde lid, Ow wijst het projectbesluit aan als schadeoorzaak, wanneer een omgevingsplan op grond van art. $5.52 \mathrm{Ow}$ wordt gewijzigd. Dit is een voorrangsregel.

Het heeft mijn voorkeur dat dergelijke regelingen (uiteindelijk) in titel 4.5 van de Awb worden opgenomen. Een getrapte besluitvorming of een samenhangend geheel van schadeveroorzakende besluiten is niet alleen kenmerkend voor het omgevingsrecht, maar komt ook in de overige delen van het bestuursrecht voor. In de huidige situatie, waarin titel 4.5 van de Awb echter niet voorziet in dergelijke bepalingen, is het wenselijk en noodzakelijk dat de bijzondere wetgever in afdeling 15.1 van de $\mathrm{Ow}$ een regeling treft voor de afbakening van schadeoorzaken.

\subsection{Noodzaak voor een uniformering van nadeelcompensatie bij infrastructurele maatregelen}

Een belangrijke categorie van schadeveroorzakende overheidshandelingen die niet onder het bereik van de nadeelcompensatieregeling in de $\mathrm{Ow}$ valt, wordt gevormd door de feitelijke werkzaamheden in verband met de realisering en het onderhoud van infrastructurele werken. Te denken valt aan het opbreken van straten of het afsluiten van bruggen en vaarwegen. Deze categorie valt thans niet onder het bereik van een wettelijke nadeelcompensatieregeling. Het is aan gemeenten om een nadeelcompensatieverordening vast te stellen, op grond waarvan burgers en ondernemers een aanvraag kunnen indienen. Niet alle gemeenten hebben echter een dergelijke nadeelcompensatieverordening vastgesteld, zodat de procedure die een benadeelde burger of ondernemer moet volgen per gemeente verschilt. Een laagdrempelige toegang tot rechtsbescherming bij de bestuursrechter tegen een afwijzende beslissing op een aanvraag om nadeelcompensatie staat op dit moment niet voor alle inwoners van Nederland open.

Bovendien hanteren overheden uiteenlopende regels voor de toekenning van nadeelcompensatie. Er is geen uniforme methode voor de berekening van de schade die 
ondernemers lijden, en er worden zeer uiteenlopende omzetdrempels gehanteerd voor de vaststelling van het normaal maatschappelijk risico.

In het verleden achtte de Afdeling bestuursrechtspraak (hierna: ABRvS) de toepassing van een drempel van $15 \%$ van de omzet op jaarbasis aanvaardbaar om te bepalen of de tijdelijke inkomensschade die veroorzaakt wordt door reguliere infrastructurele werkzaamheden boven het normaal maatschappelijk risico uitkomt. In de Wouwse Tol-uitspraak van 5 december 2012 oordeelde de Afdeling echter dat deze 15\%-omzetdrempel niet klakkeloos mag worden toegepast. ${ }^{6}$ Deze uitspraak gaf aanleiding tot discussie over de diverse drempel- en kortingspercentages die in de praktijk worden gehanteerd om het normaal maatschappelijk risico te bepalen bij schade door tijdelijke omzetdalingen die worden veroorzaakt door infrastructurele werkzaamheden. Sommige overheden hanteren nog de 15\%-omzetdrempel als uitgangspunt voor de vaststelling van het normaal maatschappelijk risico, terwijl andere (Amsterdam, Groningen en Rotterdam) in hun nadeelcompensatieregeling lagere omzetdrempels hebben opgenomen van $8 \%$ van de gemiddelde jaaromzet. Deze omzetdrempel van $8 \%$ is recentelijk in het geval van de uitspraak Cassandraplein Eindhoven van 15 juni 2106 door de Afdeling aanvaard. ${ }^{7}$

Voor de categorie infrastructurele matregelen is de inwerkingtreding van de Awb op korte termijn wenselijk om rechtsgelijkheid van burgers (en bedrijven) ten aanzien van een laagdrempelige procedure voor de afhandeling van nadeelcompensatie te bewerkstelligen. Recent is een aanzet tot uniformering van de materiële normen voor de beoordeling van aanvragen om nadeelcompensatie gedaan, met de vaststelling van de 'Handleiding nadeelcompensatie bij infrastructurele maatregelen'. Deze handleiding beoogt eenvoud, duidelijkheid en uniformiteit te brengen bij de afhandeling van deze categorie schadeveroorzakende overheidsmaatregelen.

De handleiding introduceert een relatief eenvoudige methode voor de berekening van nadeelcompensatie, waarmee voor de ondernemers een snelle inschatting van de kansen op succes mogelijk wordt. Het is aan te bevelen dat overheden de methode uit de handleiding gaan hanteren, al was het alleen maar om een uniforme beoordeling van nadeelcompensatieverzoeken te bevorderen. Daarnaast bevat de handleiding nuttige aanbevelingen voor de te volgen procedure bij de afhandeling van nadeelcompensatieverzoeken. Zo wordt aangeraden om al vooraf, dus voordat een infrastructurele maatregel wordt genomen of met de uitvoering wordt gestart, in contact te treden met belanghebbenden, zoals omwonenden, ondernemers en weggebruikers. Op die manier

6. ABRvS 5 december 2012, ECLI:NL:RVS:2012:BY5105, AB 2013/221 m.nt. Tjepkema.

7. ABRvS 15 juni 2016, ECLI:NL:RVS:2016:1650, O\&A 2016/55 m.nt. O.M. te Rijdt (Eindhoven Cassandraplein).

8. Ministerie van Binnenlandse Zaken en Koninkrijksrelaties, Handleiding nadeelcompensatie bij infrastructurele maatregelen, Den Haag 2018. kan in een vroeg stadium worden onderzocht op welke wijze hinder en schade zo veel mogelijk kunnen worden beperkt. In de praktijk blijkt dat het met vroegtijdig contact, goed overleg en een heldere communicatie inderdaad mogelijk is om schade te voorkomen of te beperken.

\section{Noodzaak voor de verschuiving van de peildatum voor de schadevergoeding}

Zoals gezegd, is een belangrijk uitgangspunt bij de vormgeving van de nadeelcompensatieregeling in de $\mathrm{Ow}$ het doorschuiven van de schadevergoeding naar de uitvoeringsfase. Een burger kan niet langer schadevergoeding vragen op het moment waarop een omgevingsplan onherroepelijk wordt, maar moet wachten totdat het omgevingsplan wordt uitgevoerd, door het verlenen van een omgevingsvergunning of het starten van een vergunningsvrije activiteit. Daarmee wordt het systeem van de 'planmaximalisatie' verlaten. Deze systeemwijziging houdt volgens de MvT verband met de integratie van sectorale regelgeving in het omgevingsplan:

'Het omgevingsplan krijgt in tegenstelling tot het bestemmingsplan het karakter van een verordening die gaat over de fysieke leefomgeving als geheel in plaats van een plan dat vooral concrete regels geeft over bouwen en grondgebruik. De verbrede reikwijdte zal tot gevolg hebben dat veel vaker dan nu het geval is, pas op basis van een concreet initiatief een representatieve inschatting van de schade kan worden gemaakt die het gevolg is van een omgevingsplan.'

De noodzaak voor het doorschuiven van de aansprakelijkheid houdt naar mijn mening ook verband met de aan de stelselherziening in het omgevingsrecht ten grondslag liggende veranderde inzichten over de verhouding tussen overheid en burger. De Ow wil voorwaarden scheppen voor een organische gebiedsontwikkeling en uitnodigingsplanologie, waarbij de overheid weliswaar de kaders en randvoorwaarden voor nieuwe ontwikkelingen in de leefomgeving vaststelt, maar bij de realisering van deze nieuwe ontwikkelingen ruimte biedt aan initiatieven en participatie van burgers en ondernemers. ${ }^{10}$ Het omgevingsplan geeft de kaders aan waarbinnen mag worden gebouwd, maar is geen blauwdruk voor nieuwe ontwikkelingen. ${ }^{11} \mathrm{Bij}$ een terugtredende overheid, die ruimte biedt aan initiatieven vanuit de markt en (slechts) de kaders en randvoorwaarden stelt die de kwaliteit van de leefomgeving moeten garanderen, past een omgevingsplan met een globale normering, die geen

9. Kamerstukken II 2017/18, 34 986, nr. 3, p. 23

10. Kamerstukken II 2017/18, 34 986, nr. 3, p. 11.

11. Kamerstukken II 2017/18, 34 986, nr. 3, p. 23. 
gedetailleerde blauwdruk vormt voor de gewenste maatschappelijke ontwikkeling, maar ondernemers en burgers uitnodigt om met initiatieven te komen die binnen de kaders van het omgevingsplan kunnen worden gerealiseerd. Bij een dergelijke visie van een terugtredende overheid past het streven naar 'globale en flexibele' omgevingsplannen met zo veel mogelijk open normen. Aan dit streven zit echter ook een keerzijde. In haar advies over het wetsvoorstel spreekt de Afdeling op tamelijk indringende wijze haar zorg uit over risico's die gepaard gaan met een vergaande mate van flexibiliteit en bestuurlijke afwegingsruimte in de $\mathrm{Ow}$. Zo is er binnen het nieuwe stelsel maar in beperkte mate sprake van materiële regels waarvan geen afwijking mogelijk is. ${ }^{12}$

'Deze risico's ontstaan in de eerste plaats door de verregaande mate van flexibiliteit in het stelsel waardoor onzeker is of burger, overheid en rechter voldoende houvast geboden wordt en ook of de bescherming uiteindelijk gelijkwaardig zal zijn an het huidige niveau. ${ }^{13}$

De Afdeling adviseert om in de Ow een specifieke evaluatieverplichting op te nemen, en dat de evaluatie zich, onder meer, op de vraag zal richten

'of de globale en flexibele omgevingsplannen, de toenemende betekenis van algemene en specifieke zorgplichten en het nieuwe systeem van nadeelcompensatie voldoende houvast bieden aan initiatiefnemer, burger, bestuurder en rechter'. ${ }^{14}$

De wens om de aansprakelijkheid door te schuiven naar de uitvoeringsfase, dat wil zeggen de verlening van een omgevingsvergunning of de start van een vergunningsvrije activiteit, acht de Afdeling op zichzelf een positieve ontwikkeling, omdat het dan niet meer gaat om hypothetische schade, maar om concrete schade. Daar staat tegenover dat het voorgestelde systeem voor nadeelcompensatie ook voor onduidelijkheden voor burgers en bedrijven kan zorgen. De Afdeling vraagt aandacht voor 'schaduwschade':

'Door de verschuiving naar het moment van uitvoering van het plan kan er een lange periode verstrijken tussen de vaststelling van het plan en het moment dat om schade kan worden verzocht. $\mathrm{Nu}$ een globaal omgevingsplan alleen een indicatie geeft van de mogelijke ontwikkelingen op een bepaalde locatie, kan dit lange tijd "boven de markt" hangen. Dit kan zogenoemde schaduwschade opleveren. ${ }^{15}$

Ook Van Heijst waarschuwt voor de consequenties van het doorschuiven van de aanspraak op schadevergoeding naar de vergunningverlening. Hij stelt dat de marktwaarde van een woning niet alleen door de feitelijke

\footnotetext{
Kamerstukken II 2017/18, 34 986, nr. 4, p. 8-12 en 24

Kamerstukken II 2017/18, 34 986, nr. 4, p. 8.

Kamerstukken II 2017/18, 34 986, nr. 4, p. 10.

Kamerstukken II 2017/18, 34 986, nr. 4, p 52.
}

situatie wordt bepaald, maar ook door verwachtingen ten aanzien van de toekomstige situatie in de directe omgeving. Een onherroepelijk omgevingsplan dat een ruimtelijke reservering bevat voor nadelige ontwikkelingen in de directe omgeving van een woning heeft een nadelig effect op de marktwaarde. Van Heijst betoogt, op basis van een uiteenzetting aan de hand van de begrippen 'marktwaarde' en 'werkelijk geleden schade', dat het doorschuiven van de aanspraak op schadevergoeding naar de vergunningverlening in combinatie met de vaste korting van $5 \%$ van de waarde vanwege het normaal maatschappelijk risico, er in de praktijk toe zal leiden dat een eigenaar zelfs bij ernstige schade niet of nauwelijks meer voor een schadevergoeding in aanmerking komt. Hij pleit ervoor om uitdrukkelijk in de wet op te nemen dat bij de waardering van een woning in de oude feitelijke situatie, op de peildatum van de verlening van de omgevingsvergunning, de waardeverminderende invloed van het omgevingsplan moet worden weggedacht. ${ }^{16}$

\section{Vergoeding van schaduwschade}

Het is algemeen erkend dat de bekendmaking van indicatieve plannen of de start van publiekrechtelijke besluitvormingsprocedures ten behoeve van ruimtelijke ontwikkelingen of grote water- en infrastructurele projecten leidt tot schade bij omwonenden en ondernemers die in de omgeving gevestigd zijn. De toekomstige ontwikkelingen die door een omgevingsvisie of omgevingsplan mogelijk worden gemaakt, 'hangen boven de markt' en de besluiten die noodzakelijk zijn om de voorgenomen ontwikkelingen te verwezenlijken, 'werpen hun schaduw vooruit'. Voor eigenaren is het in een dergelijke situatie lastiger om hun onroerende zaken te verkopen, of zij zullen moeten verkopen tegen een lagere prijs. Voor bedrijven is het lastiger (zo niet onmogelijk) om de financiering rond te krijgen voor investeringen. ${ }^{17}$ Inmiddels is er een definitie van het fenomeen schaduwschade gegeven, waarmee het bestaan ervan wordt erkend. Van Buuren omschrijft schaduwschade als:

'de schade die ontstaat als gevolg van een concreet en bekendgemaakt beleidsvoornemen of als gevolg van de voorbereiding van een schadeveroorzakend besluit'. ${ }^{18}$
16. I.P.A. van Heijst, Schadeoorzaken en schaduwschade in de nieuwe Omgevingswet, O\&A 2017/64.

17. G.M. van den Broek \& M.K.G. Tjepkema, De nadeelcompensatieregeling in de Omgevingswet: geen aantrekkelijk alternatief voor het huidige planschadestelsel, TO 2017, p. 21-33; Van den Broek \& Tjepkema 2015, par. 2.4

18. D. Sietses, De reikwijdte en rechtsgrondslag van nadeelcompensatie in het omgevingsrecht. Verslag van de jaarvergadering van Vereniging voor Bouwrecht gehouden op 10 december 2015 te Amersfoort, TBR $2016 / 34$ 
Schaduwschade ontstaat tijdens de (lange) periode van onzekerheid waarin omwonenden of ondernemers verkeren of gedurende de besluitvorming omtrent het al dan niet verwezenlijken van ruimtelijke ontwikkelingen of infrastructurele werken. Deze situatie wordt door velen als 'onrechtvaardig' gekenschetst. ${ }^{19}$ De problemen doen zich met name voor bij de voorbereiding van grote projecten, omdat de voorbereidingstijd van dergelijke projecten erg lang is. ${ }^{20}$ De discussie over de vergoeding van schaduwschade speelt al gedurende enkele decennia, waarbij steeds dezelfde argumenten worden gewisseld. De wetgever schuift het probleem voor zich uit en draait eromheen. Oplossingen werden door de wetgever steevast gezocht in een versnelling van de publiekrechtelijke procedures of werden nadrukkelijk overgelaten aan de bestuurlijke praktijk. In ons preadvies voor de Vereniging voor Bouwrecht hebben Tjepkema en ik de balans van het debat over schaduwschade opgemaakt en een eerste aanzet gegeven voor een regeling van schaduwschade. ${ }^{21}$ Vanzelfsprekend moet een regeling voor de vergoeding van schaduwschade goed worden doordacht en nader worden uitgewerkt. In de rechtswetenschappelijke literatuur zijn daartoe ook door andere auteurs bruikbare voorstellen gedaan, onder anderen door Kortmann en door Sanderink. ${ }^{22}$

In diverse reacties op de consultatieversie is vanuit de praktijk aandacht gevraagd voor het probleem van de schaduwschade. Het doorschuiven van de peildatum voor schadevergoeding van het omgevingsplan naar de verlening van een omgevingsvergunning of de start van een activiteit verlengt immers de periode van schaduwschade. ${ }^{23}$ In de rechtswetenschappelijke literatuur is aan de wetgever gevraagd om een voorziening te treffen voor de schaduwschade.

Onder de nadeelcompensatieregeling die in afdeling 15.1 van de $\mathrm{Ow}$ is opgenomen, wordt het probleem van de schaduwschade echter niet opgelost. De reikwijdte van de nadeelcompensatieregeling is immers beperkt tot besluiten die rechten en verplichtingen scheppen voor burgers. Een omgevingsvisie, programma of instructie-

19. De Nationale ombudsman, Gevangenen van een tracé. Rapport betreffende klachten over de minister van Infrastructuur en Milieu te Den Haag, 13 oktober 2013, rapportnr. 2013/144, p. 3; H.J. de Vries, Het optreden van planologische schaduwschade als gevolg van een lange planperiode zonder nadeelcompensatie te betalen: de overheid als grote profiteur!, TO 2013, afl. 4, p. 133; C.N.J. Kortmann, Schaduwschade, een conceptuele verkenning. Naar een oplossing voor de problematiek van schaduwschade door middel van een zaaksgebonden voorschot, O\&A 2017/90.

20. Dit wordt bevestigd in de toelichting bij het wetsvoorstel, p. 29

21. Van den Broek \& Tjepkema 2015, par. 2.4.

22. D.G.J. Sanderink, Het EVRM en het materiële omgevingsrecht (diss. Nijmegen), Deventer: Wolters Kluwer 2015, p. 451-510; C.N.J. Kortmann, Het omgevingsrecht als inspiratiebron voor de algemene nadeelcompensatieregeling van art. 4:126 Awb. Enige beschouwingen naar aanleiding van het preadvies voor de Vereniging voor Bouwrecht, O\&A 2016/78; Kortmann 2017.

23. D.G.J. Sanderink, Schadevaststelling bij nadeelcompensatie onder de Omgevingswet: een deels nieuwe peildatum en vergelijkingsmaatstaf, O\&A 2017/62 regel wordt nadrukkelijk niet als schadeoorzaak aangewezen. ${ }^{24}$

Wel heeft de wetgever een poging gedaan om het probleem van de verlenging van de periode van schaduwschade op te lossen. Volgens art. 15.5, eerste lid, onder a, Ow wordt aan een koper van een woning geen actieve risicoaanvaarding tegengeworpen in die gevallen waarin de aansprakelijkheid wordt doorgeschoven en de aankoop na de vaststelling van het omgevingsplan heeft plaatsgevonden. In de MvT wordt de verwachting uitgesproken dat een koper geen lagere koopprijs zal bedingen vanwege de voor hem nadelige toekomstige ontwikkelingen die mogelijk worden gemaakt door het omgevingsplan, omdat hij de mogelijkheid behoudt om een aanvraag om nadeelcompensatie in te dienen. De reacties op de regeling in art. 15.5, eerste lid, Ow zijn echter tamelijk eenduidig: de meeste auteurs verwachten dat hiermee de problematiek van de schaduwschade niet of slechts gedeeltelijk wordt weggenomen. ${ }^{25}$ De reactie van de regering op de roep om een oplossing voor de problematiek van de schaduwschade komt in wezen neer op het al decennialang gegeven weerwoord, maar nu wordt dit onderbouwd met de - overigens niet-gepubliceerde en dus niet-verifieerbare - resultaten van een onderzoek, dat bestond uit een schriftelijke vragenlijst en interviews met diverse overheden. De in de MvT gegeven argumenten van de regering zijn:

- Wanneer indicatieve plannen aanleiding kunnen geven tot schadevergoeding zullen overheden terughoudend zijn om beleidsvoornemens te publiceren, hetgeen verlammend werkt voor het bestuur.

- In de praktijk doen zich slechts enkele schrijnende gevallen van schaduwschade voor.

- Voor dit kleine aantal schrijnende gevallen moet in de praktijk door overheden en initiatiefnemers een oplossing worden gevonden.

- De oplossing kan worden gevonden in vroegtijdige participatie van bewoners, het verbeteren van het omgevingsmanagement en snellere en betere besluitvorming. ${ }^{26}$

Om de hierboven weergegeven redenen acht de regering een generieke regeling voor het oplossen van de schaduwschadeproblematiek niet nodig en ook niet gewenst. $^{27}$ In 2017 gaven Tjepkema en ik in dit tijdschrift de volgende reactie op een passage in de MvT bij de consultatieversie, waarin de regering eveneens concludeerde dat er geen noodzaak bestaat voor een generieke regeling voor de vergoeding van schaduwschade. Ik volsta op deze plaats met een herhaling van onze reactie, omdat de regering naar aanleiding van de breed geuite oproep om een oplossing te bieden voor de problematiek van de schaduwschade geen wezenlijk nieuwe argumenten heeft toegevoegd en geen inhoudelijke veranderingen heeft aangebracht in het wetsvoorstel:

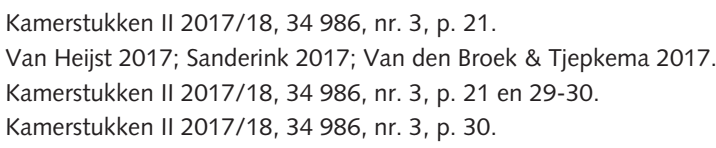


'Daarmee wordt de burger (...) afhankelijk gemaakt van de goede wil van de bestuurder om een oplossing te vinden voor een schrijnende situatie. Naar onze mening is een bredere regeling voor schaduwschade wenselijk om de burger een vangnet te bieden. De wetgever zou een voorziening moeten treffen voor die gevallen waarin een belanghebbende aannemelijk kan maken dat ernstige schade is geleden ten gevolge van een concreet en bekendgemaakt beleidsvoornemen of als gevolg van de voorbereiding van een schadeveroorzakend besluit. 28

Van Heijst is evenmin overtuigd door de motivering van de regering. Hij stelt dat de discussie over de vergoeding van schaduwschade voortdurend terug blijft komen, juist omdat zich in de praktijk steeds weer schrijnende gevallen voordoen die niet worden opgelost. Hij betoogt:

'Bij de huidige wetgeving en jurisprudentie heeft iemand die schaduwschade lijdt echter "geen poot om op te staan" en is hij geheel afhankelijk van de adhoc-bereidheid van een betrokken overheid om aan zijn schade tegemoet te komen. In de praktijk gebeurt dit alleen wanneer de betreffende overheid op enig moment een eigen belang krijgt bij een oplossing, bijvoorbeeld doordat zij dan relatief goedkoop en snel de betreffende woning kan verwerven voor haar toekomstige project. ${ }^{29}$

Ik wil nogmaals pleiten voor een wettelijke regeling die voorziet in een oplossing voor de problematiek van de schaduwschade. Dit kan door een bepaling an titel 4.5 van de Awb toe te voegen, waarin nadere voorwaarden voor de vergoeding van schaduwschade staan omschreven. De inhoudelijke criteria voor de toekenning van een vergoeding van schaduwschade zullen zijn gebaseerd op het égalitébeginsel, waarmee een te ruimhartige vergoeding van schaduwschade wordt voorkomen. Het uitgangspunt van het égalitébeginsel is immers dat alleen onevenredige schade voor vergoeding in aanmerking komt. Het valt niet te ontkennen dat een bepaalde periode van onzekerheid voor belanghebbenden inherent is aan de noodzaak van een zorgvuldige besluitvorming door de overheid. Burgers zullen gedurende een zekere periode de onzekerheid over de uitkomsten van de publiekrechtelijke besluitvormingsprocedure moeten dulden. Schaduwschade behoort in beginsel tot het normaal maatschappelijk risico. Slechts in uitzonderlijke gevallen, waarin de maatstaven van redelijkheid en billijkheid daartoe nopen, zal de vergoeding van schaduwschade aan de orde kunnen zijn. De remedie tegen een te ruimhartige vergoeding van schaduwschade kan naar mijn mening beter worden gevonden in de toepassing van inhoudelijke criteria dan in het afsluiten van de laagdrempelige bestuursrechtelijke procedure die art.

28. Van den Broek \& Tjepkema 2017.

29. Van Heijst 2017.
4:126 Awb biedt. ${ }^{30}$ Van Heijst sluit zich hierbij aan en zoekt de oplossing in het vaststellen van vaste drempels en kortingen voor het normaal maatschappelijk risico. Hij stelt voor om ten aanzien van de verschillende wettelijke instrumenten vooraf, bijvoorbeeld in een algemene maatregel van bestuur, een duidelijke drempel of korting vast te stellen voor het normaal maatschappelijk risico. ${ }^{31}$

\section{Het doorschuiven van de aansprakelijkheid naar de start van een vergunningsvrije activiteit}

De Afdeling vraagt ook aandacht voor de problemen die rijzen bij het verschuiven van de peildatum naar de start van een activiteit:

'Daarnaast is het in de situatie dat geen vergunning nodig is voor de uitvoering van het plan erg onduidelijk op welk moment het schadeveroorzakende moment zich voordoet; het kan daarbij lastig te beoordelen zijn of het feitelijk handelen in overeenstemming is met het omgevingsplan. ${ }^{32}$

Het gaat hier om schade die wordt veroorzaakt door het verrichten van vergunningsvrije activiteiten, die worden gereguleerd door de bepalingen van een omgevingsplan, waterschapsverordening of omgevingsverordening. Ik benadruk dat het hier niet gaat om overheidsaansprakelijkheid voor het verrichten van feitelijke handelingen door een bestuursorgaan, maar om het verrichten van activiteiten door een private partij, die aan een andere private partij schade toebrengen. Tjepkema en ik hebben hiertegen dogmatische bezwaren geuit, omdat de grens tussen een onrechtmatige overheidsdaad en het toebrengen van civielrechtelijke onrechtmatige hinder door een private partij dreigt te vervagen. ${ }^{33}$ De overheid kan in een dergelijke situatie slechts aansprakelijk zijn indien en voor zover de activiteit, in juridisch opzicht, mogelijk is gemaakt door een omgevingsplan of een verordening. Een burger mag deze activiteiten zonder nadere toestemming verrichten, mits wordt voldaan aan de randvoorwaarden die in het omgevingsplan of de verordening zijn gesteld.

Op het doorschuiven van de peildatum voor de schadevergoeding naar de start van een vergunningsvrije activiteit is ook door anderen kritiek geuit. Zo stellen Ten

Eerder heb ik met Tjepkema bepleit om een voorziening voor schaduwschade op te nemen in de Awb. Zie Van den Broek \& Tjepkema 2015, par. 2.4.

31. Van Heijst 2017.

32. Kamerstukken II 2017/18, 34 986, nr. 4, p. 52.

33. B. van den Broek \& M. Tjepkema, De regeling van planschadevergoeding in de Omgevingswet. Ondoordachte voorstellen met rigoureuze gevolgen, NJB 2016, afl. 38, p. 2818-2826. 
Have en Thoonen dat de schadebepaling op basis van een vergelijking van de feitelijke situatie voor en na de start van een activiteit zal leiden tot meer aanvragen om nadeelcompensatie. ${ }^{34}$ Nijmeijer vreest dat het verschuiven van het schademoment zal leiden tot meer gefragmenteerde aanvragen en wijst op allerhande bewijsperikelen ten aanzien van de aanvang van de activiteit en of er sprake is van een nieuwe activiteit dan wel de voortzetting van een oude, reeds eerder aangevangen activiteit. Hij noemt de regeling op dit punt in ieder geval gecompliceerd en waarschijnlijk niet werkbaar'. ${ }^{35}$

Naast de bovengenoemde bezwaren verwacht ik dat in het kader van de beoordeling van een verzoek om nadeelcompensatie geregeld discussie zal ontstaan over de rechtmatigheid van de activiteit of de wijze waarop de activiteit wordt verricht. De overheid is immers slechts aansprakelijk indien en voor zover de beweerdelijk geleden schade veroorzaakt wordt door een activiteit van een private partij, indien en voor zover die activiteit wordt toegestaan door, past binnen en wordt verricht in overeenstemming met het omgevingsplan, een waterschapsverordening of een omgevingsverordening. De eerste vraag die in het kader van de beoordeling van een verzoek om nadeelcompensatie moet worden beantwoord, is dan of degene die de activiteit verricht binnen de kaders van het omgevingsplan of de verordening blijft. Deze discussie speelt niet in het kader van een nadeelcompensatieverzoek dat betrekking heeft op een schadeveroorzakend appellabel besluit. Een aanvraag om nadeelcompensatie kan immers pas worden ingediend nadat het schadeveroorzakende besluit onherroepelijk is geworden, en dan wordt uitgegaan van de rechtmatigheid van het besluit. Aan een feitelijke handeling kan echter geen formele rechtskracht worden toegekend. Aangenomen dat een bestuursorgaan niet wil opdraaien voor de schade die het gevolg is van de hinder die degene die een activiteit verricht op onrechtmatige wijze aan een derde toebrengt, zal dat bestuursorgaan in het kader van de beoordeling van een aanvraag om nadeelcompensatie moeten (en willen) beoordelen in hoeverre de beweerdelijk geleden schade is veroorzaakt door een activiteit die in overeenstemming met de bepalingen van het omgevingsplan of de verordening is verricht. Ik vrees dat de afbakening tussen de aansprakelijkheid van de overheid op grond van het égalitébeginsel en de civielrechtelijke aansprakelijkheid voor het toebrengen van onrechtmatige hinder door een private partij nog voor veel discussie zal zorgen bij de beoordeling van aanvragen om nadeelcompensatie die betrekking hebben op het verrichten van activiteiten die worden toegestaan op grond van een omgevingsplan of verordening. ${ }^{36}$ Hoewel de Afdeling dit - voor de uitvoeringspraktijk

34. T. ten Have \& J.J. Thoonen, Nadeelcompensatie binnen de verbeterdoelen van de Omgevingswet, BR 2017/28.

35. A.G.A. Nijmeijer, Invoeringswet Omgevingswet: gefragmenteerde nadeelcompensatie omgevingsplan, TBR 2017/18; A.G.A. Nijmeijer, Globale omgevingsplanregels en planschaderisico: een nieuwe planschaderegeling nodig?, O\&A 2017/63.

36. Van den Broek \& Tjepkema 2017; 2016. belangrijke - punt wel in het advies heeft aangeroerd, heeft de regering hierop niet expliciet gereageerd. Naar mijn mening geeft de regering er onvoldoende blijk van dat bij het opstellen van art. 15.4 Ow de afbakeningsproblematiek met de civielrechtelijke onrechtmatige hinder is onderkend.

\section{Een vast forfait voor indirecte schade}

Art. 15.7, eerste lid, Ow bepaalt dat voor indirecte schade die bestaat uit waardevermindering van een onroerende zaak een vast forfait wordt opgenomen ter grootte van $5 \%$ van de waarde die de zaak onmiddellijk voor de peildatum heeft. De reden voor het wettelijk verankeren van een vast forfait is dat het bijdraagt aan de voorspelbaarheid van de uitkomsten van een procedure over nadeelcompensatie en aan een uniforme toepassing van het normaal maatschappelijk risico. In beginsel is een wettelijke vaste drempel of korting toe te juichen, met dien verstande dat het wenselijk is om in de wet een mogelijkheid tot afwijken op te nemen voor situaties waarin de toepassing van de vaste aftrek, gelet op alle feiten en omstandigheden van het concrete geval, niet redelijk is. Naar aanleiding van het advies van de Raad van State is in art. 15.7 Ow een vast forfait opgenomen en is het percentage vastgesteld zonder een afwijkingsmogelijkheid om toch een hoger percentage voor aftrek vast te stellen. De hoogte van een vast forfait van 5\% sluit niet aan bij de huidige praktijk en jurisprudentie. ${ }^{37}$ In de jurisprudentie wordt een forfait van $5 \%$ als relatief hoog bestempeld. Een dergelijke hoge aftrek mag slechts in een specifieke categorie gevallen worden gehanteerd, en er worden zware eisen gesteld aan de motivering. Een hoger forfait dan $5 \%$ van de waarde is voor schade in de vorm van waardevermindering niet gebruikelijk, het komt veel vaker voor dat een lager forfait wordt gehanteerd.

In de nadeelcompensatiejurisprudentie is in sommige gevallen waarin de aanvraag betrekking had op schade in de vorm van waardevermindering van woningen als gevolg van een aantasting van het woongenot, een relatief hoge drempel van $5 \%$ van de waarde van de onroerende zaak aanvaard. ${ }^{38}$ De schadeveroorzakende maatregelen werden in deze zaken gekwalificeerd als normale maatschappelijke ontwikkelingen, die bovendien plaatsvonden binnen een gebied waar reeds een verhoogde kans bestond op (nadelige) ontwikkelingen, zoals de

37. F.A. Mulder, Normaal maatschappelijk risico bij nadeelcompensatie onder de Omgevingswet; nog steeds een ruimhartige regeling?, O\&A 2017/66. Een uitgebreide beschrijving en analyse van de jurisprudentie inzake art. 6.2 Wro is te vinden in Van den Broek \& Tjepkema 2015, hoofdstuk 3.

38. ABRvS 19 februari 2014, AB 2015/183 m.nt. Tjepkema (Schiphol) en ABRvS 9 april 2014, AB 2015/184 m.nt. Tjepkema (Kustversterking Noordwijk). 
omgeving van de luchthaven Schiphol en het kustgebied.

Ook in de planschadejurisprudentie is een - in verhouding tot het wettelijke forfait van $2 \%$ in art. 6.2, tweede lid, Wro - verhoogd forfait van 5\% slechts gebruikelijk voor een specifieke categorie van schadeveroorzakende maatregelen. ${ }^{39}$ Het betreft normale maatschappelijke ontwikkelingen, zoals inbreiding in een bestaande woonwijk waarbij, kort samengevat, geen sprake is van onevenredig zware schade en de maatregel in de lijn der verwachtingen ligt, gelet op het ruimtelijke beleid en op de structuur van de omgeving. ${ }^{40}$ In deze situatie acht de Afdeling een waardevermindering tot 5\% van de waarde van de onroerende zaak 'substantieel, maar niet zodanig zwaar dat deze schade niet voor rekening van de aanvrager kan worden gelaten'. ${ }^{41}$ De $5 \%$ is zeker geen standaarddrempel en aan de motivering om dit relatief hoge percentage te kunnen hanteren, worden zware eisen gesteld. Wanneer een nieuwe ontwikkeling niet past binnen het tot dan toe gevoerde ruimtelijke beleid of de structuur van de omgeving, of wanneer sprake is van onevenredig zware schade, kan een lager percentage voor het normaal maatschappelijk risico worden gehanteerd, waarbij in veel gevallen een forfait wordt gehanteerd van ongeveer $3 \%$. ${ }^{42}$

Er is dus een bandbreedte zichtbaar in de jurisprudentie, het gehanteerde forfait schommelt al naar gelang de omstandigheden van het geval tussen $2 \%$ en $5 \%$.

Wanneer de wetgever kiest voor een wettelijk verankerd forfait, zou gekozen moeten worden voor een regeling die meer aansluit bij de jurisprudentie en die ruimte biedt om bij de toepassing van het forfait recht te doen aan de omstandigheden van het geval. Tjepkema en ik hebben verschillende varianten voorgesteld van regelingen die een dergelijke bandbreedte behelzen. ${ }^{43}$ Een andere mogelijkheid dan een bandbreedte is een regeling waarin een forfait van 5\% als uitgangspunt wordt genomen, maar waarin een afwijkingsmogelijkheid is opgenomen om, gelet op de concrete omstandigheden van het geval, een lager of geen percentage vast te stellen.

Een derde mogelijkheid is om, naar analogie van art. 4:126 Awb, geen vast forfait in de wet op te nemen, maar de rechtsontwikkeling over te laten aan de rechter. Hoewel deze derde mogelijkheid aanvankelijk minder lijkt bij te dragen aan de voorspelbaarheid van de uitkomsten van de beoordeling van een aanvraag, zijn er inmiddels in de jurisprudentie belangrijke aanknopingspunten gegeven voor de afbakening van het normaal

39. Een uitgebreide beschrijving en analyse van de jurisprudentie inzake art. 6.2 Wro is te vinden in Van den Broek \& Tjepkema 2015, hoofdstuk 3.

40. ABRvS 2 maart 2016, ECLI:NL:RVS:2016:530.

41. ABRvS 28 september 2016, ECLI:NL:RVS:2016:2582, AB 2016/399 m.nt. Tjepkema en Van den Broek.

42. ABRvS 8 juni 2016, ECLI:NL:RVS:2016:1602, OGR 2016-0122 m.nt. Van den Broek; ABRvS 17 mei 2017, ECLI:NL:RVS:2017:1293, TBR 2017/149 m.nt. G.M. van den Broek (Compensatie in natura Winkelcentrum De Lunet); ABRvS 28 maart 2018, ECLI:NL:RVS:2018:1050; ABRvS 3 oktober 2018, ECLI:NL:RVS:2018:3192 (Lunet/Breda), TBR 2018/176 m.nt. B.S. ten Kate.

43. Van den Broek \& Tjepkema 2015; 2017. maatschappelijk risico. Bovendien heeft de ABRvS de jurisprudentie inzake het hanteren van een vaste drempel en/of korting voor de toepassing van het normaal maatschappelijk risico geüniformeerd door in planschade- en nadeelcompensatiezaken dezelfde standaardoverwegingen te hanteren. In recente planschadejurisprudentie toont de Afdeling zich bereid en in staat om de hoogte van de waardedrempel vol te toetsen en zo nodig zelf in de zaak te voorzien door haar eigen oordeel over de juiste hoogte van de drempel in de plaats te stellen van het oordeel van het bestuursorgaan. ${ }^{44}$ Ten aanzien van de toepassing van het normaal maatschappelijk risico is er in jurisprudentie van de afgelopen jaren sprake van standaardisering en uniformering. Wanneer de wetgever in de $\mathrm{Ow}$ een vast forfait opneemt, dat afwijkt van de jurisprudentie en van de nadeelcompensatieregeling in de Awb, is het nog maar de vraag of de trend tot uniformering kan worden voortgezet. Bovendien zal dit hoge forfait er in de praktijk, zeker in combinatie met het doorschuiven van de aansprakelijkheid naar de uitvoeringsfase, toe leiden dat de meeste aanvragen om nadeelcompensatie niet meer zullen worden gehonoreerd. Dat verhoogt natuurlijk de voorspelbaarheid van de uitkomsten van een nadeelcompensatieprocedure, maar Mulder stelt (terecht) de vraag aan de orde of daarvan een positieve impuls uitgaat naar de gebiedsontwikkeling. Hij verwacht dat, wanneer de meeste nadeelcompensatieclaims op voorhand kansloos zijn, er meer beroepen zullen worden ingesteld tegen de schadeveroorzakende besluiten, zoals het omgevingsplan en de omgevingsvergunning. ${ }^{45}$

\section{Slotbeschouwing}

In deze bijdrage heb ik onderzocht of de regering naar aanleiding van de reacties op de consultatieversie van 5 januari 2017 en het advies van de Afdeling advisering van de Raad van State wijzigingen heeft aangebracht in het wetsvoorstel voor een nadeelcompensatieregeling in afdeling 15.1 van de $\mathrm{Ow}$.

Mijn conclusie is dat de drie fundamentele keuzes voor de vormgeving van de nadeelcompensatieregeling niet of nauwelijks zijn gewijzigd. De verschillende reacties en adviezen hebben voornamelijk geleid tot een uitgebreidere motivering en onderbouwing in de MvT.

Met het wetsvoorstel Invoeringswet Omgevingswet is gekozen voor een aparte nadeelcompensatieregeling in afdeling 15.1 van de Ow. Deze zal gelden als een lex specialis ten opzichte van titel 4.5 van de Awb. Het is de bedoeling dat de algemene nadeelcompensatieregeling in de Awb tegelijkertijd met de $\mathrm{Ow}$ in werking treedt. Met de keuze voor een bijzondere nadeelcompensatieregeling in de $\mathrm{Ow}$ zet de regering een streep door de keuze die de wetgever in 2013 makte voor een uniforme nadeelcompensatieregeling in de Awb.

44. ABRvS 21 september 2016, AB 2016/440 m.nt. M.K.G. Tjepkema.

45. Mulder 2017 
Bovendien beoogt het voorstel voor een nadeelcompensatieregeling in de $\mathrm{Ow}$ ingrijpende wijzigingen van het huidige planschade- en nadeelcompensatierecht. De veranderingen worden door de regering noodzakelijk geacht in verband met de stelselherziening in het omgevingsrecht. De consequenties van deze stelselherziening beperken zich niet tot het omgevingsrecht, maar strekken zich uit tot de algemene leerstukken van het bestuursrecht, zoals de nadeelcompensatie.

In diverse reacties vanuit de praktijk, in de rechtswetenschappelijke literatuur en door de Afdeling advisering van de Raad van State zijn zorgen geuit over de keuzes die de wetgever heeft gemaakt bij de vormgeving van de nadeelcompensatieregeling in de Ow. De combinatie van globale en flexibele plannen, het doorschuiven van de aansprakelijkheid voor indirecte schade naar de uitvoeringsfase, waardoor de periode van schaduwschade wordt verlengd, en het hoge vaste forfait bij indirecte schade leidt tot de verwachting dat er in de toekomst ook in gevallen van ernstige schade niet of nauwelijks een vergoeding zal worden toegekend.

De keuze om de vergoedingen voor indirecte schade in zo verregaande mate te beperken, sluit niet aan bij de huidige jurisprudentie en de praktijk. Het is een politieke keuze, en het debat daarover behoort in de Tweede Kamer te worden gevoerd. 